\title{
Germ Cell Apoptosis After Treatment of Cryptorchidism with Human Chorionic Gonadotropin is Associated with Impaired Reproductive Function in the Adult
}

\author{
Leo Dunkel, ${ }^{*}$ Seppo Taskinen, ${ }^{\star}$ Outi Hovatta, ${ }^{\ddagger}$ Jonathan L. Tilly, ${ }^{\S}$ and Sakari Wikström* \\ *Children’s Hospital, University of Helsinki, FIN-00290 Helsinki, Finland; ${ }^{\ddagger}$ Infertility Clinic, The Family Federation of Finland, \\ FIN-00100 Helsinki, Finland; and the ${ }^{\S}$ Vincent Center for Reproductive Biology, Department of Obstetrics and Gynecology, \\ Massachusetts General Hospital/Harvard Medical School, Boston, Massachusetts 02114
}

\begin{abstract}
Cryptorchidism results in impaired fertility. Reduced numbers of testicular germ cells can be shown histologically during the first years of life. The process causing germ cell loss in cryptorchid prepubertal boys is unknown, but it could be the result of a form of programmed cell death known as apoptosis. 25 adult men with a history of surgically treated cryptorchidism were studied, 15 of whom had received an unsuccessful human chorionic gonadotropin (hCG) therapy before orchidopexy. Apoptotic DNA fragmentation was assayed in testis biopsies taken during orchidopexy by endlabeling, both in extracted DNA and histochemically in situ. Only a few scattered apoptotic spermatogonias were seen by end-labeling of biopsies from patients not treated with hCG, whereas more extensive labeling of spermatogonia was seen after hCG treatment. As estimated by gel electrophoresis, the amount of low molecular weight DNA was 4.3-fold higher in the hCG-treated group when compared with the level in scrotal testis of non-hCG-treated patients $(P<0.001)$. About 20 yr after the biopsy, the low molecular weight DNA fragmentation correlated negatively with the testis volume $(r=-0.84 ; P<0.001)$ and positively with serum FSH levels $(r=0.73 ; P<0.001)$. Findings in the semen analysis were similar between the groups. Apoptotic loss of spermatogonia after hCG treatment of cryptorchidism warrants reevaluation of the safety of this treatment. (J. Clin. Invest. 1997. 100:2341-2346.) Key words: DNA fragmentation • fertility $\bullet$ infertility $\bullet$ male reproduction
\end{abstract}

\section{Introduction}

Cryptorchidism is the most common congenital abnormality in newborn boys. The incidence of cryptorchidism has increased during the last few decades (1) from $\sim 1$ to $1.5 \%$. It is a serious risk factor for testicular cancer (2) and an important cause of infertility (3).

The pathogenesis of the reduced fertility seen in cryptorchidism has not been fully clarified. Several previous studies have detailed the morphometric features of cryptorchid testes

Address correspondence to Leo Dunkel, M.D., Children's Hospital, University of Helsinki, FIN-00290 Helsinki, Finland. Phone: 011-3580-471-4725; FAX: 011-358-9-471-5888; E-mail: leo.dunkel@sci.fi

Received for publication 25 March 1997 and accepted in revised form 12 September 1997.

J. Clin. Invest.

(C) The American Society for Clinical Investigation, Inc. 0021-9738/97/11/2341/06 \$2.00

Volume 100, Number 9, November 1997, 2341-2346

http://www.jci.org during the first years of life (4-6). The germ cell counts of cryptorchid testes is within normal limits during the first year of postnatal life. They fall below the normal range between 1 and $2 \mathrm{yr}$ of age, reaching the lowest level of germ cells per tubule at $\sim 2$ yr of age (4-6). The reduced fertility has been linked to the reduced number of germ cells because the cryptorchid patients with the lowest total germ cell counts have the poorest spermiograms in adulthood (7).

Recently, it was found that in the rat testis germ cell death takes place through the process of programmed cell death (apoptosis) characterized by internucleosomal fragmentation of DNA $(8,9)$. Furthermore, apoptosis in the testis has been found to be hormonally regulated by androgens and gonadotropins (8-10). The major objective of this study was to examine the occurrence of apoptotic germ cell death in the human testis. We found increased apoptotic germ cell death after human chorionic gonadotropin $\left(\mathrm{hCG}^{1}\right.$ treatment of cryptorchidism. Therefore, we also assessed the possible long-term consequences of the hCG treatment-induced germ cell death in prepuberty on reproductive parameters in adult life. We studied 25 adult men who underwent orchidopexy, including testis biopsies in prepuberty, with or without preceding hCG treatment, to achieve these goals.

\section{Methods}

Subjects. The subjects of our study were originally treated for cryptorchidism at the Children's Hospital, University of Helsinki, or in the Aurora Hospital, Helsinki, Finland. 25 adult men with history of cryptorchidism treated operatively were examined. Before surgical treatment 15 patients had received unsuccessful hCG treatment, which consisted of 10 intramuscular injections over a period of $5 \mathrm{wk}$. A single dose for patients younger than seven years old was 500 IU, and for patients older than seven years old, $1000 \mathrm{IU}$. The remaining ten boys were operated on without prior hormonal treatment. 21 of the patients had been treated for unilateral cryptorchidism, and 4 had been treated for bilateral cryptorchidism. All undescended testes were located either in inguinal, prepubic, or high scrotal position. Since intraabdominally located testes are particularly associated with poor prognosis for fertility, no such patients were included in our study. During orchidopexy, testicular biopsies were taken, fixed in Steve's fixative, and embedded in paraffin. The time interval between the last hCG injection and testicular biopsy varied from 1 to $4 \mathrm{wk}$ in cases of prior unsuccessful hCG treatment. Testicular biopsies, taken from the normally descended testis during the operation for unilateral cryptorchidism from nine age-matched boys, served as controls (11). On orchidopexy the age of the patients varied from 10 mo to 13 $\mathrm{yr}$, and on followup examination from 16 to $30 \mathrm{yr}$.

Testicular volumes were measured by using a ruler and the formula $0.71 \times$ length $\times$ width $^{2}(12)$. The sperm was collected after a minimum of $2 \mathrm{~d}$ of abstinence. Semen analysis was done within $2 \mathrm{~h}$

1. Abbreviations used in this paper: $\mathrm{hCG}$, human chorionic gonadotropin; LHRH, luteinizing hormone-releasing hormone. 
and interpreted according to the World Health Organization 1992 criteria (13). The results of the semen analysis were considered normal when the sperm concentration was at least $20 \times 10^{6}$ spermatozoa $/ \mathrm{ml}$, the percentage of spermatozoa with progressive motility was at least $50 \%$, and at least $30 \%$ of the spermatozoa had a normal morphology. Plasma testosterone was measured by RIA after separation of steroid fractions on a Lipidex-5000 microcolumn (Packard-Becker, B.V. Chemical Operations, Groningen, The Netherlands). Plasma LH and FSH concentrations were measured by time-resolved IFMAs, using reagents from LKB-Wallac (Turku, Finland).

DNA isolation and analysis for fragmentation. Genomic DNA was extracted from paraffin-embedded testicular tissue and quantified by absorbance at $260 \mathrm{~nm}(14,15)$. After extraction, one microgram of DNA from each sample was labeled at the $3^{\prime}$-ends with $\left(\alpha-{ }^{32} \mathrm{P}\right)$ dideoxyATP $(3,000 \mathrm{Ci} / \mathrm{mmol}$; Amersham Corp., Arlington Heights, IL) using $25 \mathrm{U}$ terminal transferase (Boehringer-Mannheim Biochemicals, Indianapolis, IN) $(14,16)$. A 1-kb DNA molecular-weight ladder (Gibco-BRL, Gaithersburg, MD) was also labeled (100 ng) using the same method as a control. The labeled DNA samples were loaded onto $2 \%$ agarose gels (200 ng/lane for testicular specimens) and separated by electrophoresis for $3 \mathrm{~h}$ at $50 \mathrm{~V}$. The gels were dried for $2 \mathrm{~h}$ in a slab-gel drier and exposed to Kodak X-OMAT films (Eastman Kodak Co., Rochester, NY) at $-70^{\circ} \mathrm{C}$ for $2-6 \mathrm{~h}$ and analyzed by autoradiography and $\beta$-counting of low molecular weight $(<10 \mathrm{~kb})$ DNA fractions (14). After autoradiography, apoptosis, with its internucleosomally cleaved DNA fragments, could be identified by its typical ladder pattern.

In situ 3'-end labeling of DNA. For in situ detection of DNA fragmentation in the testes, we used a nonradioactive DNA 3 '-end labeling method, based on principals as described above $(14,17,18)$. The fixed, paraffin-embedded testes were sectioned at $5 \mu \mathrm{m}$ and mounted on slides coated with Vectabond (Vector Laboratories Inc., Burlingame, CA), deparaffinized, and hydrated. To remove the mercury compound included in the acidic Steve's fixative, and to neutralize the histological sections, we first soaked the slides in Gram's iodine for $5 \mathrm{~min}$ and then left them for $30 \mathrm{~min}$ in $100 \mathrm{mM}$ Tris $(\mathrm{pH} 8)$.

Proteinase-K treatment of $20 \mathrm{~min}$ at $37^{\circ} \mathrm{C}(5 \mu \mathrm{g} / \mathrm{ml}$ in $20 \mathrm{mM}$ Tris, $2 \mathrm{mM} \mathrm{CaCl}$, $\mathrm{pH}$ 7.4; Boehringer-Mannheim) was followed by incubation for $10 \mathrm{~min}$ in terminal transferase buffer $(200 \mathrm{mM}$ potassium cacodylate, $25 \mathrm{mM}$ Tris, $0.25 \mathrm{mg} / \mathrm{ml} \mathrm{BSA}, 5 \mathrm{mM} \mathrm{CoCl}$; $\mathrm{pH}$ 6.6) at room temperature. DNA 3 '-end labeling with digoxigenin-ddUTP was done by adding terminal transferase ( $1 \mathrm{U} / \mu \mathrm{l}$; Boehringer-Mannheim), digoxigenin-ddUTP (5 $\mu \mathrm{M}$; Boehringer-Mannheim), and ddATP (45 $\mu \mathrm{M}$; Pharmacia Fine Chemicals, Uppsala, Sweden) in fresh buffer and incubating the sections in this solution at $37^{\circ} \mathrm{C}$ for $1 \mathrm{~h}$.

After labeling, the slides were washed three times for $10 \mathrm{~min}$ at room temperature in buffer $1(100 \mathrm{mM}$ Tris, $150 \mathrm{mM} \mathrm{NaCl}, \mathrm{pH} 7.5)$ and then incubated with buffer $2(100 \mathrm{mM}$ Tris $/ 150 \mathrm{mM} \mathrm{NaCl}, \mathrm{pH} 7.5$, $0.5 \% \mathrm{wt} / \mathrm{vol}$ blocking-reagent; Boehringer-Mannheim) for $30 \mathrm{~min}$ at room temperature. Antidigoxigenin antibody conjugated with alkaline phosphatase was next added to this buffer $(1: 8,000$ in $0.5 \% \mathrm{wt} / \mathrm{vol}$ buffer 2), and the sections were incubated with the antibody at room temperature in a humidified chamber for $2 \mathrm{~h}$.

Three 10-min washes in buffer 1 were followed by equilibration in buffer 3 (100 mM Tris, $100 \mathrm{mM} \mathrm{NaCl}, 50 \mathrm{mM} \mathrm{MgCl}$; $\mathrm{pH} 9.5)$, after which substrates for alkaline phosphatase $(337.5 \mu \mathrm{g} / \mathrm{ml}$ nitroblue tetrazolium, and $175 \mu \mathrm{g} / \mathrm{ml}$ 5-bromo-4-chloro-3-inodyl-phosphate; Boehringer-Mannheim) were added. The color reaction was allowed to develop for $\sim 20 \mathrm{~min}$, and was terminated by soaking the slides in buffer 4 (10 mM Tris, $1 \mathrm{mM}$ EDTA; $\mathrm{pH} 8)$ for $5 \mathrm{~min}$. The stained sections were then mounted with coverslips, and the extent of apoptosis was analyzed by light microscopy $(400 \times)$ ). For each section (depending on its size), five to ten randomly selected fields were analyzed. The analysis was done without any prior knowledge of the sample.

Quantitative analysis of apoptosis. The quantitation of apoptosis was performed both biochemically and histochemically. In the biochemical analysis, the extent of internucleosomal DNA cleavage in isolated DNA, a widely accepted hallmark of apoptosis, was used.
The level of apoptotic DNA cleavage per $200 \mathrm{ng}$ of total DNA in biopsies taken from cryptorchid testes was expressed relative to the corresponding level of DNA cleavage observed in the scrotal testes (control or normal background). This method of quantitation has clear advantages since the DNA extracted from biopsies represents a larger sampling of the tissue than could be obtained from histochemical analysis. Furthermore, the level of apoptotic DNA cleavage reflects specifically the extent of germ cell apoptosis since the apoptotic cells possessing fragmented DNA were identified in situ as being exclusively spermatogonia. In the histochemical analysis, the level of apoptosis was assessed by counting the number of apoptotic cells (spermatogonia) labeled by the $3^{\prime}$-end labeling reaction in tissue sections relative to the total number of Sertoli cells. The level of apoptosis was expressed as a ratio of apoptotic spermatogonia to Sertoli cells in each biopsy specimen.

Statistical analysis. Because of the small number of patients with bilateral cryptorchidism, statistical analyses were only done for the patients with unilateral cryptorchidism. ANOVA was used to analyze the effects of hCG treatment, age, and testicular position. Further comparisons between separate groups were done by Fisher's Protected Least Significant Difference and by unpaired Student's $t$ test. Fisher's exact test was then applied in a $2 \times 2$ table to analyze the difference between the hCG-treated and non-hCG-treated groups.

\section{Results}

Apoptotic DNA fragmentation after treatment with $h C G$. Testicular DNA isolated from samples obtained from prepubertal boys was analyzed using $3^{\prime}$-end labeling with terminal transferase, followed by gel fractionation and autoradiography. Samples were obtained from all boys for autoradiography and quantitation. In testis biopsy specimens from boys who had not received hCG treatment for cryptorchidism, no or little internucleosomal DNA fragmentation was visible, even with the highly sensitive method we used to analyze DNA integrity (Fig. $1 \mathrm{~A}$ ). This finding was consistent both in the scrotal (control) and in the cryptorchid testes. In contrast, the ladder pattern showing the internucleosomal DNA fragmentation typical of apoptosis was pronounced in samples obtained from testes after unsuccessful treatment of cryptorchidism with hCG (Fig. $1 A$ ). Quantification with low molecular weight DNA $(<10 \mathrm{~kb})$ showed that testicular DNA from boys not having received hCG treatment for cryptorchidism consistently dis-

Table I. Number of Patients with Unilateral and Bilateral Cryptorchidism Divided by Treatment and Low Molecular Weight DNA Fragmentation in the Undescended Testis

\begin{tabular}{|c|c|c|}
\hline & \multicolumn{2}{|c|}{$\begin{array}{l}\text { Relative level of low } \\
\text { molecular weight DNA }\end{array}$} \\
\hline & Normal* & Elevated ${ }^{\ddagger}$ \\
\hline \multicolumn{3}{|c|}{ hCG treatment before the operation } \\
\hline Yes & 1 & 14 \\
\hline No & 10 & 0 \\
\hline \multicolumn{3}{|c|}{$\begin{array}{l}\text { * Normal levels of low molecular DNA cleavage were based on results } \\
\text { obtained from biopsies of control subjects (scrotal testes of nine prepu- } \\
\text { bertal boys, no prior hCG treatment). In cryptorchid boys, values below } \\
\text { the } 95 \% \text { confidence limit were considered normal. }{ }^{\ddagger} \text { Values above the } \\
95 \% \text { confidence limit were considered elevated. Fisher's Exact } P \text { value } \\
<0.0001 \text {. }\end{array}$} \\
\hline
\end{tabular}


A
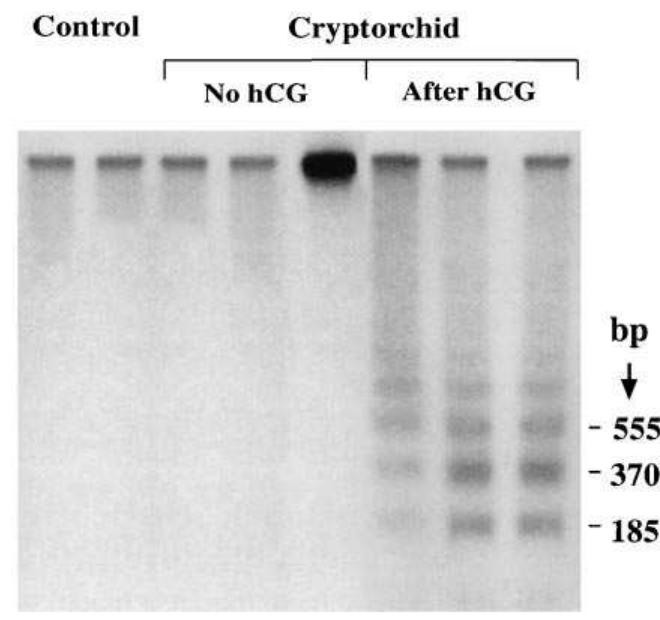

B

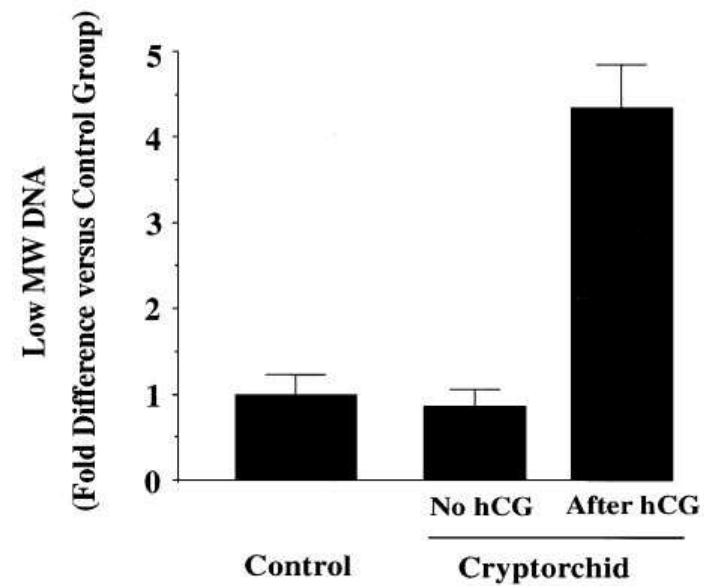

Figure 1. Analysis of DNA integrity in human testicular biopsy specimens, indicating the effect of hCG treatment. $(A)$ Autoradiography showing eight representative DNA ladder patterns of testes from patients without and with preceding unsuccessful treatment with hCG. For this detection method, one microgram of DNA from each biopsy sample was isolated before labeling its $3^{\prime}$-ends with $\left[\alpha^{32} \mathrm{P}\right] \mathrm{ddATP}$ (400 ng/reaction). The DNA samples were then loaded on agarose gels and separated by electrophoresis. Evidence of apoptosis, indicated by the occurrence of internucleosomal DNA breakdown into 185-basepair (bp) multiples, is observed in the testis after hCG treatment, whereas little or no DNA fragmentation is observed in the scrotal (control) or cryptorchid testes without preceding treatment with hCG. (B) Quantitative analysis of DNA integrity, based on all testis biopsy specimens $(n=25)$ assessed by $\beta$-counting of the low molecular weight $(<10 \mathrm{~kb})$ DNA fractions following electrophoresis. Mean \pm SEM of data demonstrate that significantly increased apoptotic DNA cleavage occurs in the cryptorchid testis only after treatment with hCG.

played very low levels of DNA fragmentation both in the scrotal and in the cryptorchid testes. In contrast, the mean amount of low molecular weight DNA in samples taken after hCG treatment was 4.3-fold higher when compared with the control samples of scrotal testes, obtained without prior hCG treatment $(P<0.001$, Fig. $1 B)$. The levels of low molecular weight DNA between hCG-treated and non-hCG-treated patients did not overlap, and the levels of low molecular weight DNA were neither dependent on the age nor the location of the cryptorchid testis. Furthermore, when the levels were assessed as either normal or elevated based on the findings in the controls from scrotal testes, the two groups of cryptorchid boys were almost completely separated (Table I).
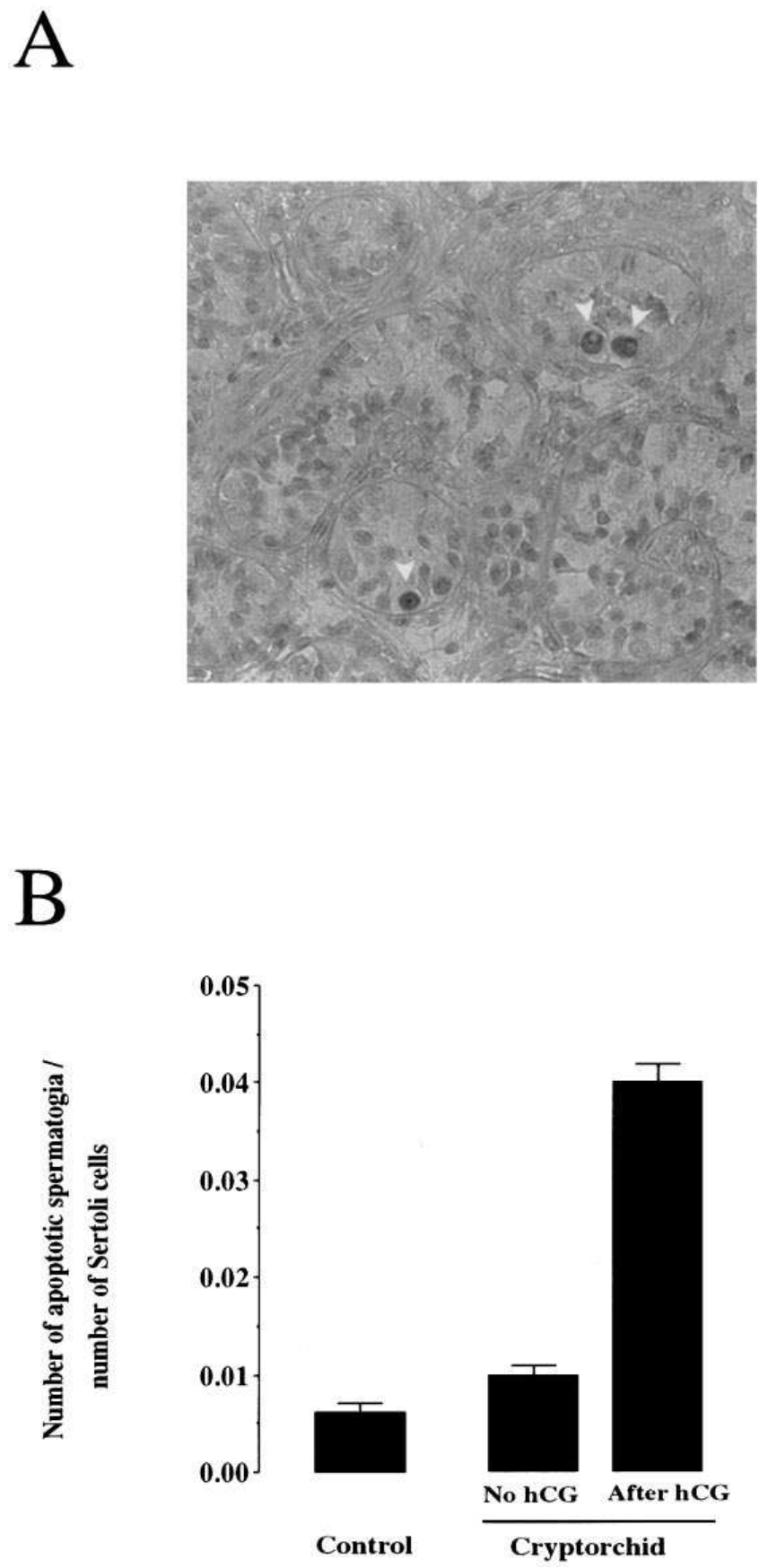

Figure 2. Apoptotic cell death in spermatogonia of the human testis. $(A)$ The biopsy taken from a 5-yr-old boy 3 wk after unsuccessful treatment with hCG. The histological sections were stained with an in situ $3^{\prime}$-end labeling method in which the digoxigenin-ddUTP label is detected by antidigoxigenin antibodies conjugated to alkaline phosphatase. Arrows indicate apoptotic cells. 400×. (B) Quantitative analysis of $3^{\prime}$-end labeled cells, as expressed per total number of Sertoli cells. Mean \pm SEM of data demonstrate significantly increased $3^{\prime}$ end labeled (apoptotic) spermatogonia in the cryptorchid testis only after treatment with hCG. 
In situ analysis of DNA fragmentation. To find out the specific cell types with increased DNA fragmentation, in situ $3^{\prime}$ end labeling with digoxigenin-ddUTP was done on paraffinembedded sections of testes from boys with and without prior hCG treatment. In prepubertal boys, spermatogenesis had progressed to late mitotic cells, and histological sections indicated the presence of spermatogonia and possibly a few primary spermatocytes. The majority of the sections of the seminiferous tubules showed no labeled cells with the in situ $3^{\prime}$-end labeling method in boys not having received hCG treatment. A few of the apoptotic cells were localized in some tubules, and were identified as being exclusively spermatogonia (Fig. $2 \mathrm{~A}$ ). These apoptotic spermatogonias appeared as single cells scattered around the testis, however, some sections of the seminiferous tubule contained more positively staining cells than others. In hCG-treated boys, the number of seminiferous tubules with DNA labeling was increased, which was consistent with observed increases in apoptotic fragmentation of the whole testis DNA. Also, in the samples taken after hCG treatment, the cell types that showed increased labeling were found to be spermatogonia.

For quantitative analysis, the number of the $3^{\prime}$-end labeled spermatogonia were expressed per total number of Sertoli cells. The mean number of apoptotic spermatogonia was 6.7-fold higher when compared with the control samples of scrotal testes, obtained without prior hCG treatment ( $P<0.001$, Fig. 2 B).

Adult hCG-treated versus non-hCG-treated patients. Having found increased apoptotic germ cell death after treatment of cryptorchidism with hCG in testis biopsies taken $\sim 20 \mathrm{yr}$ ago, we assessed the possible long-term consequences of the hCG treatment-induced germ cell death in prepuberty on reproductive functions in adult life. Because of the small number of patients with bilateral cryptorchidism (two hCG-treated, two nontreated patients), statistical analyses were only done for the patients with unilateral cryptorchidism, although the results were consistent in boys with unilateral and bilateral cryptorchidism. When the cryptorchid patients were divided according to the levels of DNA fragmentation, those patients who had exhibited elevated DNA fragmentation also had smaller testis volumes and higher serum FSH levels than those with normal levels of low molecular weight DNA (Table II). Serum $\mathrm{LH}$ and testosterone levels were similar between the two groups. Furthermore, no differences were observed in any of the parameters of the semen analysis, although a tendency for poorer semen quality was seen in patients with elevated levels of low molecular weight DNA (Table II). A significant negative correlation was found between the level of low molecular weight DNA and the testis volume in adulthood (Fig. 3). Furthermore, the level of low molecular weight DNA positively correlated with serum FSH levels. The three patients with the highest level of DNA fragmentation were those who had supranormal serum FSH levels (i.e., > 10 IU/L) (Fig. 3).

\section{Discussion}

Using the gel fractionation and in situ analysis of DNA fragmentation, this study provides biochemical evidence of apoptotic cell death in testicular germ cells in prepubertal boys. Testicular DNA analyzed by $3^{\prime}$-end labeling followed by autoradiography showed that the levels of apoptotic (internucleosomal) DNA fragmentation in the cryptorchid testis is increased after treatment of cryptorchidism with hCG. In situ analysis further demonstrated DNA fragmentation in spermatogonia in a subpopulation of seminiferous tubules. Furthermore, the levels of apoptotic cell death after treatment with hCG correlate with testis volume (negative) and serum FSH levels (positive) in adult life, suggesting that these findings have direct clinical relevance. The testis is very vulnerable in prepubertal life, and several factors that negatively affect the germ cells in prepuberty can cause disruptions of germ cell development and subsequent hypogonadism. Since cryptorchid patients have reduced numbers of germ cells, these patients may not be able to adequately compensate for any further reduction in germ cell numbers induced by hCG treatment.

Cell death may occur by two different mechanisms: necrosis and apoptosis (19). In apoptosis, a specific endonuclease cleaves the cell's DNA at internucleosomal sites to form multimers of 180-200 basepairs, a precise phenomenon which has been largely accepted as the hallmark of apoptosis (20). Observations on the morphological changes in the cell reveal nuclear and cytoplasmic condensation and breakage of the cell into several membrane-bound apoptotic bodies. These bodies are then rapidly phagocytosed by macrophages or by other neighboring cells. Apoptosis has been observed in many differ-

Table II. Various Parameters of Reproductive Function in Adult Patients Treated Operatively for Unilateral Cryptorchidism in Prepuberty

\begin{tabular}{|c|c|c|c|c|c|c|}
\hline & \multicolumn{3}{|c|}{ hCG treatment } & \multicolumn{3}{|c|}{ Relative level of low molecular weight DNA } \\
\hline & No & Yes & $P=$ & Normal* & Elevated & $P=$ \\
\hline Testis volume $(\mathrm{mL})$ & $20.6 \pm 2.3$ & $10.8 \pm 1.4$ & 0.0009 & $20.3 \pm 2.0$ & $10.1 \pm 1.4$ & 0.0002 \\
\hline Serum FSH (IU/liter) & $3.1 \pm 0.3$ & $6.2 \pm 1.0$ & 0.05 & $3.0 \pm 0.3$ & $6.5 \pm 1.1$ & 0.008 \\
\hline Serum LH (IU/liter) & $3.9 \pm 0.6$ & $4.2 \pm 0.3$ & NS & $4.0 \pm 0.5$ & $4.1 \pm 0.4$ & NS \\
\hline Serum testosterone (nmol/liter) & $20.6 \pm 2.7$ & $21.1 \pm 2.0$ & NS & $20.6 \pm 2.3$ & $21.1 \pm 2.3$ & NS \\
\hline Sperm concentration (cells* $10^{6} / \mathrm{mL}$ ) & $77.8 \pm 17.7$ & $89.7 \pm 13.0$ & NS & $84.1 \pm 16.6$ & $84.3 \pm 13.7$ & NS \\
\hline Normal sperm motility $(\mathrm{A}+\mathrm{B}, \%)$ & $75.4 \pm 8.2$ & $56.6 \pm 8.3$ & NS & $73.0 \pm 7.5$ & $56.6 \pm 9.8$ & NS \\
\hline Normal sperm morphology (\%) & $44.0 \pm 6.1$ & $30.6 \pm 6.3$ & NS & $43.1 \pm 5.4$ & $29.5 \pm 7.3$ & NS \\
\hline
\end{tabular}

Subjects were divided into two groups according to the treatment or the levels of low molecular weight DNA fragmentation in the undescended testis $(n=21)$. The biopsies were taken in prepuberty during orchidopexy. Values are mean \pm SEM. *Normal levels of low molecular DNA cleavage were based on results obtained from biopsies of control subjects (scrotal testes of nine prepubertal boys, no prior hCG treatment). In cryptorchid boys, values below the $95 \%$ confidence limit were considered normal. ${ }^{*}$ Values above the $95 \%$ confidence limit were considered elevated. 


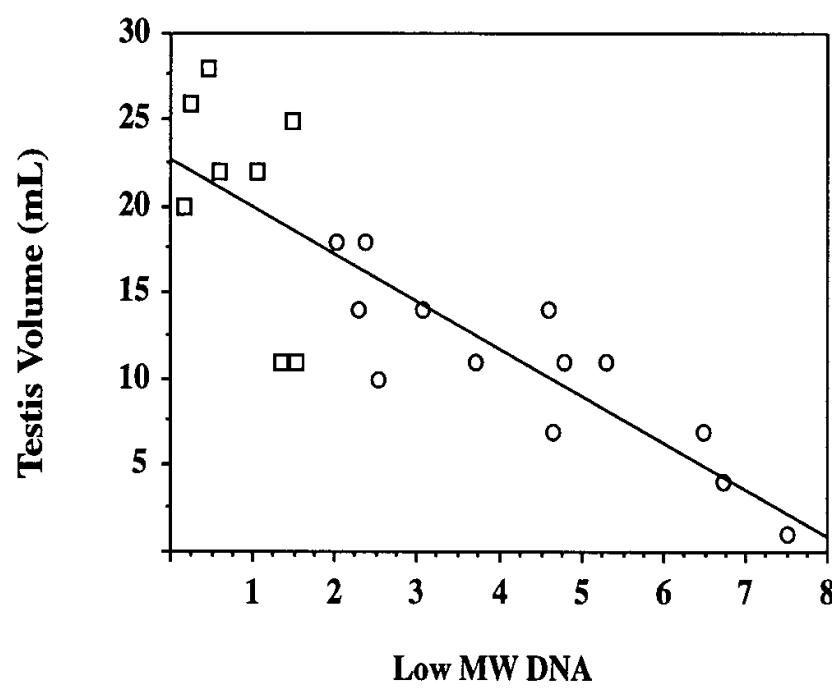

(Fold Difference versus Control Group)

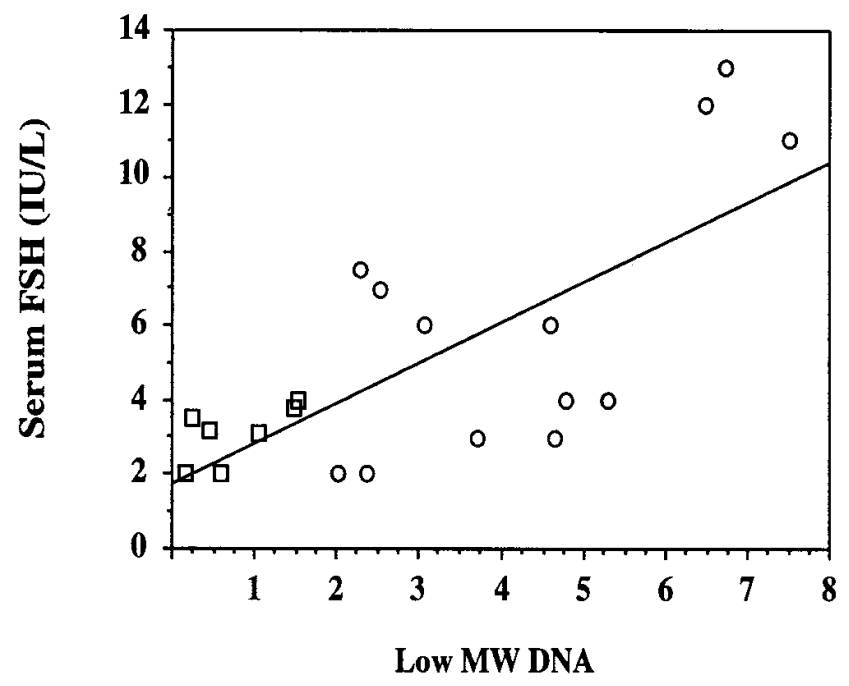

(Fold Difference versus Control Group)

Figure 3. Correlations between the relative levels of low molecular weight DNA fragmentation and adult testis volume $(r=-0.84 ; P<$ $0.001)$ and serum FSH level $(r=0.73 ; P<0.001)$ in patients treated for unilateral cryptorchidism with (circles) and without (squares) hCG in prepuberty.

ent tissues, both healthy and neoplastic; it typically involves single scattered cells, and since it progresses rapidly, it is difficult to observe (20). Apoptosis may be caused by noxious agents, but unlike necrosis, it primarily occurs after a physiological stimulus such as a surge or a withdrawal of a hormone (19-21).

On the basis of morphological analysis, germ cell degeneration during spermatogenesis was recognized almost a century ago (22). Germ cell deletion during normal spermatogenesis has been estimated to result in the loss of up to $75 \%$ of the potential numbers of mature sperm cells in the adult testis (2325). In the rat, peaks of germ cell loss have been shown in three distinct stages of spermatogenesis: during mitotic divi- sions of type A spermatogonia, during meiotic divisions of spermatocytes, and during spermiogenesis (24).

Consistent with the recent data derived from studies of the rat testis, the cell types showing biochemical evidence of apoptosis in human testis were spermatogonia (9). It is established that spermatogenesis is gonadotropin-dependent, and optimal function of the testis is supported by FSH and by intratesticular androgens induced by luteinizing hormone. Hypophysectomy or neutralization of circulating gonadotropins increases degeneration of spermatogenic cells (26-28). In addition, some data indicate that the drop in serum testosterone levels also causes apoptosis in germ cells of the testis, especially among haploid cells (29). Since serum testosterone levels are increased during the 5-wk hCG treatment by about 150 to 200fold, followed by a decrease to low prepubertal levels within a few weeks (30), we assume that the increase in germ cell apoptosis after hCG treatment seen in this study most likely reflects the androgen withdrawal effect.

An interesting finding was that the patients having had hCG treatment for cryptorchidism, compared with the nonhCG-treated patients, had smaller testis volume as adults. These findings suggest that normal development of the testis is disrupted by the hCG treatment, possibly through the mechanism of increased apoptotic germ cell death. We could note a tendency of poorer sperm quality in patients having received hCG treatment before operation, but none of the differences were significant, most likely due to the compensating effect of the scrotal testis in cases of unilateral cryptorchidism. The small number of patients with bilateral cryptorchidism available for this study did not allow us to substantiate the effect of hCG treatment on sperm production.

In the numerous studies of semen analysis from men after cryptorchidism, there is considerable variation in the percentage of patients with azoospermia and oligospermia (31-39). In an analysis of 27 published studies, the percentages of patients with azoospermia or oligospermia have been shown to be roughly similar for the groups that had surgical treatment, hormonal treatment, or combinations of both (34). Unsuccessful hCG treatment followed by orchidopexy, however, seems to result in a higher prevalence of azoospermia than orchidopexia alone (56\% compared with $42 \%$, respectively) (34).

Hormonal treatment of cryptorchidism was introduced in 1930, and the first hormone used was hCG (40, 41). Cryptorchidism has also been treated with synthetic analogs of LHreleasing hormone (LHRH) (42-44), and combined hormonal therapy with hCG and LHRH (45-47). The success rates have been reported to vary from 0 to $55 \%$ with hCG (48) and from 9 to $78 \%$ with LHRH (49). Recently an extensive metaanalysis of 33 articles containing a total of 3,282 boys with 4,524 cryptorchid testes showed that the success rates with hCG and LHRH are similar (19 and $21 \%$, respectively), but different from placebo (4\%) (50). The side effects of various treatments have not been extensively studied. One recent investigation reported an increase in intravascular leukocyte aggregation, and an increase in volume density of testicular blood vessels as well as the occurrence of interstitial bleeding, in the testes of hCGtreated boys (51). Along these lines, previous studies have indicated that hCG causes inflammation-like changes in both human and animal testes $(52,53)$. In this study we demonstrate that treatment with hCG is followed by an increase in germ cell apoptosis, which in turn is associated with smaller testis volume and higher FSH levels in adulthood. In summary, we 
propose that because of poor treatment success rates and now clearly shown side effects, the potential hazards of hCG treatment on the testis should be critically reevaluated.

\section{Acknowledgments}

Supported by the Sigrid Juselius Foundation, Finland.

\section{References}

1. Cryptorchidism: a prospective study of 7500 consecutive male births, 1984-8. John Radcliffe Hospital Cryptorchidism Study Group. 1992. Arch. Dis. Child. 67:892-899.

2. Martin, D.C. 1982. Malignancy in the cryptorchid testis. Urol. Clin. North. Am. 9:371-376.

3. Kogan, S.J. 1987. Fertility in cryptorchidism. An overview in 1987. Eur. J. Pediatr. 146:21-24.

4. Hedinger, E. 1982. Histopathology of undescended testes. Eur. J. Pediatr. 139:266-271.

5. Schindler, A.M., P. Diaz, A. Cuendet, and P.C. Sizonenko. 1987. Cryptorchidism: a morphological study of 670 biopsies. Helv. Paediatr. Acta. 42:145-158.

6. Huff, D.S., F. Hadziselimovic, H.M. Snyder III, J.W. Duckett, and M.A. Keating. 1989. Postnatal testicular maldevelopment in unilateral cryptorchidism. J. Urol. 142:546-548.

7. Hadziselimovic, F., B. Herzog, B. Hocht, E. Hecker, E. Miescher, and M. Buser. 1987. Screening for cryptorchid boys risking sterility and results of longterm buserelin treatment after successful orchidopexy. Eur. J. Pediatr. 146:59-62.

8. Tapanainen, J., J.L. Tilly, K. Vihko, and A.J.W. Hsueh. 1993. Hormonal control of apoptotic cell death in the testis: gonadotropins and androgens as testicular cell survival factors. Mol. Endocrinol. 7:643-650.

9. Billig, H., I. Furuta, C. Rivier, J. Tapanainen, M. Parvinen, and A.J.W. Hsueh. 1995. Apoptosis in testis germ cells: developmental changes in gonadotropin dependence and localization to selective tubule stages. Endocrinology. 136:5-12.

10. Sinha Hikim, A.P., C. Wang, A. Leung, and R. Swerdloff. 1995. Involvement of apoptosis in the induction of germ cell degeneration in adult rats after gonadotropin-releasing hormone antagonist treatment. Endocrinology. 136: $2770-2775$.

11. Heiskanen, P., H. Billig, J. Toppari, M. Kaleva, A. Arsalo, J. Rapola, and L. Dunkel. 1996. Apoptotic cell death in the normal and cryptorchid human testis: the effect of human chorionic gonadotropin on testicular cell survival. Pediatr. Res. 40:351-356.

12. Taskinen, S., M. Taavitsainen, and S. Wikström. 1996. Measurement of testicular volume: comparison of 3 different methods. J. Urol. 155:930-933.

13. WHO laboratory manual for the examination of human semen and semen-cervical mucus interaction. 1992. Cambridge University Press, Cambridge.

14. Tilly, J.L., and A.J.W. Hsueh. 1993. Microscale autoradiographic method for qualitative and quantitative analysis of apoptotic DNA fragmentation. J. Cell. Physiol. 154:519-526.

15. Gross-Bellard, M., P. Oudet, and P. Chambon. 1973. Isolation of highmolecular-weight DNA from mammalian cells. Eur. J. Biochem. 36:32-38.

16. Tilly, J.L. 1994. Use of terminal transferase DNA labeling reaction for the biochemical and in situ analysis of apoptosis. In Cell Biology: A Laboratory Handbook. J.E. Celis, editor. Academic Press, Inc., San Diego. 330-337.

17. Gavrieli, Y., Y. Sherman, and S.A. Ben-Sasson. 1992. Identification of programmed cell death in situ via specific labeling of nuclear DNA fragmentation. J. Cell Biol. 119:493-501.

18. Billig, H., I. Furuta, and A.J.W. Hsueh. 1993. Estrogens inhibit and androgens enhance ovarian granulosa cell apoptosis. Endocrinology. 133:22042212 .

19. Buja, L.M., M.L. Eigenbrodt, and E.H. Eigenbrodt. 1993. Apoptosis and necrosis: basic types and mechanisms of cell death. Arch. Pathol. Lab. Med. 117:1208-1214.

20. Schwartzman, R.A., and J.A. Cidlowski. 1993. Apoptosis: the biochemistry and molecular biology of programmed cell death. Endocr. Rev. 14:133-151.

21. Majno, G., and I. Joris. 1994. Apoptosis, oncosis, and necrosis. An overview of cell death. Am. J. Pathol. 146:3-15.

22. Regaud, C.P. 1900. Degenerescence des cellules seminales chez mammiferes en l'abscence de tout etat pathologique. CR. Soc. Biol. 52:268-270.

23. Oakland, E. 1956. A description of spermatogenesis in the mouse and its use in analysis of the cycle of seminiferous epithelium and germ cell renewal. Am. J. Anat. 99:391-413.

24. Huckins, C. 1978. The morphology and kinetics of spermatogonial degeneration in normal adult rats: an analysis using a simplified classification of germinal epithelium. Anat. Rec. 190:905-926.
25. De Rooij, D.G., and D. Lok. 1987. Regulation of the density of spermatogonia in the seminiferous epithelium of the Chinese hamster: II. Differentiating spermatogonia. Anat. Rec. 217:131-136.

26. Russel, L.D., L.E. Alger, and L.G. Nequin. 1987. Hormonal control of pubertal spermatogenesis. Endocrinology. 120:1615-1632.

27. Clermont, Y., and H. Morgentaler. 1955. Quantitative study of spermatogenesis in the hypophysectomized rats. Endocrinology. 57:369-382.

28. Raj, L.D., and M. Dym. 1976. The effects of selective withdrawal of FSH and LH on spermiogenesis in the immature rat. Biol. Reprod. 14:489-494.

29. Troiano, L., M. Faustini Fustini, E. Lovato, A. Frasoldati, W. Malorni, M. Capri, E. Grassilli, P. Marrama, and C. Franceschi. 1994. Apoptosis and spermatogenesis: evidence from an in vivo model of testosterone withdrawal in the adult rat. Biochem. Biophys. Res. Comm. 202:1315-1321.

30. Dunkel, L., J. Perheentupa, and D. Apter. 1985. Kinetics of the steroidogenic response to single versus repeated doses of human chorionic gonadotropin in boys in prepuberty and early puberty. Pediatr. Res. 19:1-4.

31. Albescu, J.Z., C. Bergada, and M. Cullen. 1971. Male fertility in patients treated for cryptorchidism before puberty. Fertil. Steril. 22:829-833.

32. Lipshultz, L.I., T.R. Caminos, C.S. Greenspan, and P.J. Snyder. 1976. Testicular function after orchidopexy for unilaterally undescended testis. $N$. Engl. J. Med. 295:15-18.

33. Knorr, D. 1979. Fertility after hCG-treatment of maldescended testes. Pediat. Adolesc. Endocrinol. 6:215-223.

34. Chilvers, C., N.E. Dudley, M.H. Gough, M.B. Jackson, and M.C. Pike. 1986. Undescended testis: the effect of treatment on subsequent risk of subfertility and malignancy. J. Pediatr. Surg. 21:691-696.

35. Puri, P., and B. O'Donnell. 1988. Semen analysis of patients who had orchidopexy at or after seven years of age. Lancet. 2:1051-1052.

36. Okuyama, A., N. Nonomura, M. Nakamura, M. Namiki, H. Fujioka, H. Kiyohara, K. Matsumoto, and T. Sonoda. 1989. Surgical management of undescended testis: retrospective study of potential fertility in 274 cases. J. Urol. 142: 749-751.

37. Cendron, M., M.A. Keating, D.S. Huff, C.E. Koop, H.M. Snyder III, and J.W. Duckett. 1989. Cryptorchidism, orchidopexy and infertility: a critical long-term retrospective analysis. J. Urol. 142:559-562.

38. Grasso, M., A. Buonaguidi, C. Lania, F. Bergamaschi, M. Castelli, and P. Rigatti. 1991. Postpubertal cryptorchidism: review and evaluation of the fertility. Eur. Urol. 20:126-128.

39. Cortes, D., and J. Thorup. 1991. Histology of testicular biopsies taken at operation for bilateral maldescended testes in relation to fertility in adulthood. Br. J. Urol. 68:285-291.

40. Schapiro, B. 1930. Kann man mit Hypofysenvordenlappen den unterentwickelten männlichen Genitalapparat beim Menschen zum Wachstum anregen? Dtsch. Med. Wochenschr. 56:556.

41. Schapiro, B. 1931. Ist der Kryptorchismus chirurgish oder hormonal zu behandeln? Dtsch. Med. Wochenschr. 57:718.

42. Bartsch, G., and J. Frick. 1974. Therapeutic effects of luteinizing hormone releasing hormone (LH-RH) in cryptorchidism. Andrologia. 6:197-201.

43. Happ, J., F. Kollmann, C. Krawehl, M. Neubauer, and J. Beyer. 1975. Intranasal GnRH therapy of maldescended testes. Horm. Metab. Res. 7:440-441.

44. Hadziselimovic, F., D. Huff, J. Duckett, B. Herzog, J. Elder, H. Snyder, and M. Buser. 1987. Treatment of cryptorchidism with low doses of buserelin over a 6-months period. Eur. J. Pediatr. 146:56-58.

45. Hadziselimomovic, F., J. Girard, B. Herzog, and G. Stalder. 1982. Hormonal treatment of cryptorchidism. Horm. Res. 16:188-192.

46. Hagberg, S., and O. Westphal. 1987. Results of combined hormonal and surgical treatment for undescended testis in boys under 3 years of age. Eur. J. Pediatr. 146:38-39.

47. Waldschmidt, J., M. El-Dessouky, and A. Priefer. 1987. Therapeutic results in cryptorchidism after combination therapy with LH-RH nasal spray and HCG. Eur. J. Pediatr. 146:31-34.

48. De Muink Keizer-Schrama, S.M.P.F. 1988. Hormonal treatment of cryptorchidism. Horm. Res. (Basel). 30:178-186.

49. Schwarz, H.P., S. Aebi, and A. Perisic. 1989. Success and relapse rate after treatment of cryptorchidism with intranasal LHRH. Acta Pediatr. Scand. 74: 274-280.

50. Pyörälä, S., N.-P. Huttunen, and M. Uhari. 1995. A review and metaanalysis of hormonal treatment of cryptorchidism. J. Clin. Endocrinol. Metab. 80:2795-2799

51. Hjertkvist, M., G. Lackgren, L. Ploen, and A. Bergh. 1993. Does hCG treatment induce inflammation-like changes in undescended testes in boys? $\mathrm{J}$. Pediatr. Surg. 28:254-258.

52. Bergh, A., J.-E. Damber, and A. Widmark. 1988. Hormonal control of testicular blood flow, microcirculation and vascular permeability. In The Molecular and Cellular Endocrinology of the Testis, Volume 50. B.A. Cooke, and R.M. Sharpe, editors. Raven, New York. 123-133.

53. Kerr, J.B., and R.M. Sharpe. 1989. Focal disruption of spermatogenesis in the testis of adult rats after a single administration of human chorionic gonadotropin. Cell. Tissue Res. 257:163-169. 